\title{
In-water methods reveal population dynamics of a green turtle Chelonia mydas foraging aggregation in the Philippines
}

\author{
Gonzalo Araujo ${ }^{1, *}$, Christine G. M. Legaspi ${ }^{1}$, Sophie Ferber ${ }^{1}$, Ryan Murray ${ }^{1}$, \\ Kathryn Burdett ${ }^{1}$, Summer Grundy ${ }^{1}$, Jessica Labaja ${ }^{1}$, Sally Snow ${ }^{1}$, \\ Arnel Yaptinchay ${ }^{2}$, Alessandro Ponzo ${ }^{1}$
}

${ }^{1}$ Large Marine Vertebrates Research Institute Philippines, Jagna, Bohol 6308, Philippines

${ }^{2}$ Marine Wildlife Watch of the Philippines, Bonifacio Global City, Taguig 1634, Philippines

\begin{abstract}
The green turtle Chelonia mydas is an Endangered species that forms aggregations at neritic foraging sites where juveniles spend, in some cases, over a decade before moving to adult- or subadult-dominated foraging sites. Here, we used photographic identification, behavioural observations, paired-laser and stereo-photogrammetry to determine the population dynamics of a coastal aggregation of green turtles in Oslob, Philippines. We identified a total of 82 individual turtles between May 2012 and October 2018. We recorded behavioural observations during individual identification and found that turtles changed behaviour in $25 \%$ of instances. Some turtles were identified consistently throughout the study period, indicating strong site fidelity and residency. Modified maximum likelihood models suggest turtles spend the majority of their time within the study area (>92\%), although some $(8 \%)$ excursions outside the area do occur. Markrecapture models suggest this foraging aggregation exhibits a pattern similar to that of a closed population. This is likely due to the extended residency periods of some individuals at the site, and the relatively low recruitment rate over time. We measured 18 turtles using paired-laser photogrammetry, with estimated straight carapace length of $55.3 \mathrm{~cm}$, and mean growth rates of $3.4 \mathrm{~cm}$ $\mathrm{yr}^{-1}$. Stereo-photogrammetry measurements were consistent and more accurate than visual or paired-laser photogrammetry estimates. Our results highlight the use of in-water methods to understand population dynamics of green turtles, and the importance of coastal, juvenile-dominated habitats for green turtles, as well as the need for effective conservation and management strategies to safeguard them.
\end{abstract}

KEY WORDS: Population demographics $\cdot$ Photogrammetry $\cdot$ Photo-ID $\cdot$ Growth rates $\cdot$ Behaviour $\cdot$ Chelonid

\section{INTRODUCTION}

The green turtle Chelonia mydas (Linnaeus, 1758) is a circumglobal species of marine turtle that inhabits tropical, subtropical and temperate waters (Groombridge \& Luxmoore 1989). It is listed in Appendix I of the Convention on International Trade in Endangered Species of Wild Fauna and Flora

\footnotetext{
${ }^{*}$ Corresponding author: g.araujo@lamave.org
}

(CITES), and in Appendices I and II of the Convention of Migratory Species (CMS). The species is listed as Endangered in the IUCN Red List of Threatened Species due to continued exploitation and population declines of some populations across all major ocean basins (Seminoff 2004). Coupled with the take of eggs (Cruz 2002) and the direct and indirect take of juveniles and adults (Wallace et al. 2010), other

() The authors 2019. Open Access under Creative Commons by Attribution Licence. Use, distribution and reproduction are unrestricted. Authors and original publication must be credited. 
threats such as climate change (Baker et al. 2006, Solomon et al. 2007), degradation of nesting and foraging habitats (Duran Najera 1990, Eckert et al. 1999) and ingestion of debris and plastics (Bugoni et al. 2001) hinder recovery of green turtle populations. Understanding their life history and associated habitats in detail is therefore of utmost importance in order to design informed conservation strategies.

In the Philippines, turtle conservation spans almost 4 decades with the creation of the Task Force Pawikan through an executive order in 1979, and the inclusion of turtle species in the Wildlife Resources Conservation and Protection Act of 2001 (RA-9417). However, turtle populations have declined substantially over the past century from direct take of adults and juveniles for their carapace and meat as well as egg harvesting for consumption across the country (Cruz 2002). A more recent study revealed indigenous communities legally taking turtles and harvesting eggs, but then illegally selling these in a growing black market (Poonian et al. 2016). Most of the work to date (Trono 1991, Chaloupka 2001, Cruz 2002, Sagun 2004, Lejano \& Ingram 2007) has focused on the largest green turtle rookery in Southeast Asia, the Turtle Islands Heritage Protected Area (TIHPA), a bilaterally protected area between the Philippines and Malaysia in the southwest Sulu Sea (Pilcher 2007). Based on flipper tagging data, nesting turtles from TIHPA travel across the Philippines and cross international boundaries (Sagun 2004). The government of the Philippines is pushing for the creation of a network of marine protected areas (MPAs) to protect known nesting sites and migratory routes within the Sulu Sulawesi Seascape, including TIHPA, El Nido-Taytay in northern Palawan and Tubbataha Reefs Natural Park (TRNP) in the central Sulu Sea. Little work, however, has focused on foraging turtles (TRNP as the exception), despite substantial evidence indicating nesters from other countries forage in the Philippine archipelago (e.g. Sagun 2003, Maison et al. 2010, Dutton et al. 2014, Pilcher et al. 2019). Understanding their local habitat use, population ecology and demographics is a research priority, as highlighted by Wildermann et al. (2018).

One technique commonly used to study green turtle population ecology and demographics is the application of individual flipper tags. Tagging programmes have been employed across their range, with some studies extending over decadal time scales (e.g. Union Creek, Bahamas; Bjorndal et al. 2005). Tagging typically involves the live-capture of a turtle and the attachment of a plastic or metal tag with a unique number to its flippers, along with the documentation of other parameters (e.g. size, weight, etc.; Limpus 1992). Tagged turtles need to be subsequently recaptured to determine growth, residency and other population demographics, or to examine migration patterns (e.g. Sagun 2003). Tags, however, have the risk of detaching from the turtles (e.g. Reisser et al. 2008), and if this happens, the identification and data from these turtles is lost (Limpus 1992). The risks of injury and stress are also of concern when capturing a wild animal for tagging purposes. To minimise these risks and in areas where live-capture of turtles is logistically or politically impossible, less invasive in-water techniques can be employed to address some of these concerns.

In other marine taxa, photographic identification (photo-ID) has been used for capture-mark-recapture (CMR) studies, such as sperm whales Physeter macrocephalus (Whitehead 2001), whale sharks Rhincodon typus (Araujo et al. 2017) and raggedtooth sharks Carcharhinus taurus (Van Tienhoven et al. 2007). Photo-ID typically employs natural markings on animals that can be individually identified and do not change over time. This method relies on photographic 'captures' and 'recaptures' with no need to physically handle the animals or 'mark' them. In marine turtles, the use of photo-ID has proliferated in recent years (Reisser et al. 2008, Schofield et al. 2008, Jean et al. 2010, Chassagneux et al. 2013, Dunbar et al. 2014, Carpentier et al. 2016), opening new opportunities to study these animals in their natural environments whilst minimising disturbance (Araujo et al. 2016). Photo-ID of green turtles relies on their unique facial scute patterns, which are reportedly stable for at least $11 \mathrm{yr}$ (Carpentier et al. 2016). Although longer-term data sets (i.e. decadal) are needed to fully understand their stability, photo-ID can be used to understand some population demographics (e.g. residency; Araujo et al. 2016).

Another in-water technique that can be employed to understand the dynamics of a population is pairedlaser photogrammetry. This technique can be used to size individual animals within a population by projecting 2 laser dots, set at a known distance apart, onto the target animals while recording video or photographs (Rohner et al. 2011). Size data for vulnerable species is important as it can be used to determine several factors, including growth rates (Bjorndal \& Bolten 1988), size-at-maturity (Rohner et al. 2015) or overexploitation (Jennings \& Kaiser 1998), amongst others. Although for turtles, size-atmaturity cannot be externally determined (Limpus \& Chaloupka 1997), photogrammetry has been used to determine the age class of a foraging aggregation 
(e.g. Araujo et al. 2016). Similarly, stereo-photogrammetry can be used to measure free-swimming marine animals (Santana-Garcon et al. 2014). This technique employs 2 cameras mounted at a preset angle and distance on a frame, which are calibrated with specialised software to extrapolate linear distances within captured images (see Shortis \& Abdo 2016). This system has been used for measuring sharks with $<5 \%$ error (Klimley \& Brown 1983), shallow-water fish with an operating error of $0.2-0.7 \%$ (Harvey et al. 2004) and baleen whales with a 3\% error (Spitz et al. 2000). Given the accuracy of this approach, and the recent improvement and accessibility of the system via the use of relatively low-cost action cameras and open source software (Shortis \& Abdo 2016), stereo-photogrammetry can be a useful technique for validating other broadly determined size estimates made using methods such as visual estimates (Araujo et al. 2017). This latter method relies on researchers visually estimating the size of an animal in-water based on objects of known lengths (e.g. swimmers, boats), but is known to carry an inherently high degree of error (Rohner et al. 2015, Sequeira et al. 2016).

Understanding the growth of individuals within a population is important for life-history models (Bjorndal \& Bolten 1988). Typically, CMR studies record the curved carapace length (CCL) or the straight carapace length (SCL) of individual turtles through capture, and then growth rates are measured at a later stage after recapture (Bjorndal \& Bolten 1988). The SCL or CCL can then be calculated to determine the growth rate of the individual (Seminoff et al. 2002). Growth rates in green turtles vary greatly across populations and can be influenced by temperature, diet, competition, genetics and age (Bjorndal et al. 2000). The range is from $0.9-10.7 \mathrm{~cm} \mathrm{yr}^{-1}$ (summary in Andrade et al. 2016), and shows monotonic (e.g. Caribbean) or non-monotonic (e.g. west Pacific) growth amongst individuals of varying sizes (Limpus \& Chaloupka 1997, Bjorndal et al. 2000). Photogrammetry coupled with photo-ID can, in theory, be employed to determine growth rates, although this has not yet been tested on marine turtles.

Here, we investigated the use of in-water methods to determine the population dynamics of a foraging aggregation of green turtles in the Visayas region of the Philippines. We used photo-ID and modified maximum likelihood methods to model residency, population size, mortality and lagged identification rate (LIR). We used laser photogrammetry to measure size and growth, and stereo-photogrammetry to test the accuracy of visual size estimates and laser measurements. We report behavioural observations of tur- tles in-water and discuss the usability and importance of these data.

\section{MATERIALS AND METHODS}

\subsection{Study site}

Our study was conducted in a demarked area in the waters of barangay (village) Tan-awan, ca. $14 \mathrm{~km}$ south of the town of Oslob, Cebu Province (Fig. 1). A detailed description of the study site is given in Araujo et al. (2016), but briefly, a $\sim 65000 \mathrm{~m}^{2}$ demarked area is used between 06:00 and 12:30 $\mathrm{h}$ as an interaction area where whale shark Rhincodon typus, Smith 1828 feeding attracts $>500000$ tourists $\mathrm{yr}^{-1}$ (Local Government Unit, Oslob unpub. data for 2018). During tourism hours, fishing is not permitted in the demarked area.

Seagrass represents the majority of the substrate 2-9 m deep within the interaction area. We conducted haphazard point transects across this area and identified the seagrasses as Cymodocea rotundata, C. serrulata, Halodule uninervis, H. pinifolia, Halophila ovalis, Syringodium isoetifolium, Enhalus acoroides and Thalassia hemprichii (Fig. 1C). Patchy coral over sand dominates from 9-16 m deep (Fig. 1C). Green turtles are typically encountered either foraging on seagrass meadows (primarily on $H$. uninervis, $H$. ovalis and $T$. hemprichii), resting on or under coral reef structures or free-swimming anywhere within the interaction area.

\subsection{Turtle surveys, photographic identification and behavioural observations}

Turtle surveys lasted $1 \mathrm{~h}$ and were conducted between January 2015 and October 2018. Turtles were opportunistically encountered outside dedicated surveys, and photo-ID and behavioural data were also collected on such occasions, including some from 2012, 2013 and 2014. Surveys involved 1 researcher, who snorkelled from shore and haphazardly searched for turtles within the demarked area. Upon encountering a turtle, the researcher recorded the initial behaviour of the turtle, categorised as feeding, swimming or resting. Following classification of that initial behaviour, researchers photographed the turtle's facial scutes, perpendicular to the animal, prioritising the left facial side. A photograph of the right facial scutes and carapace were also collected to aid identification when possi- 


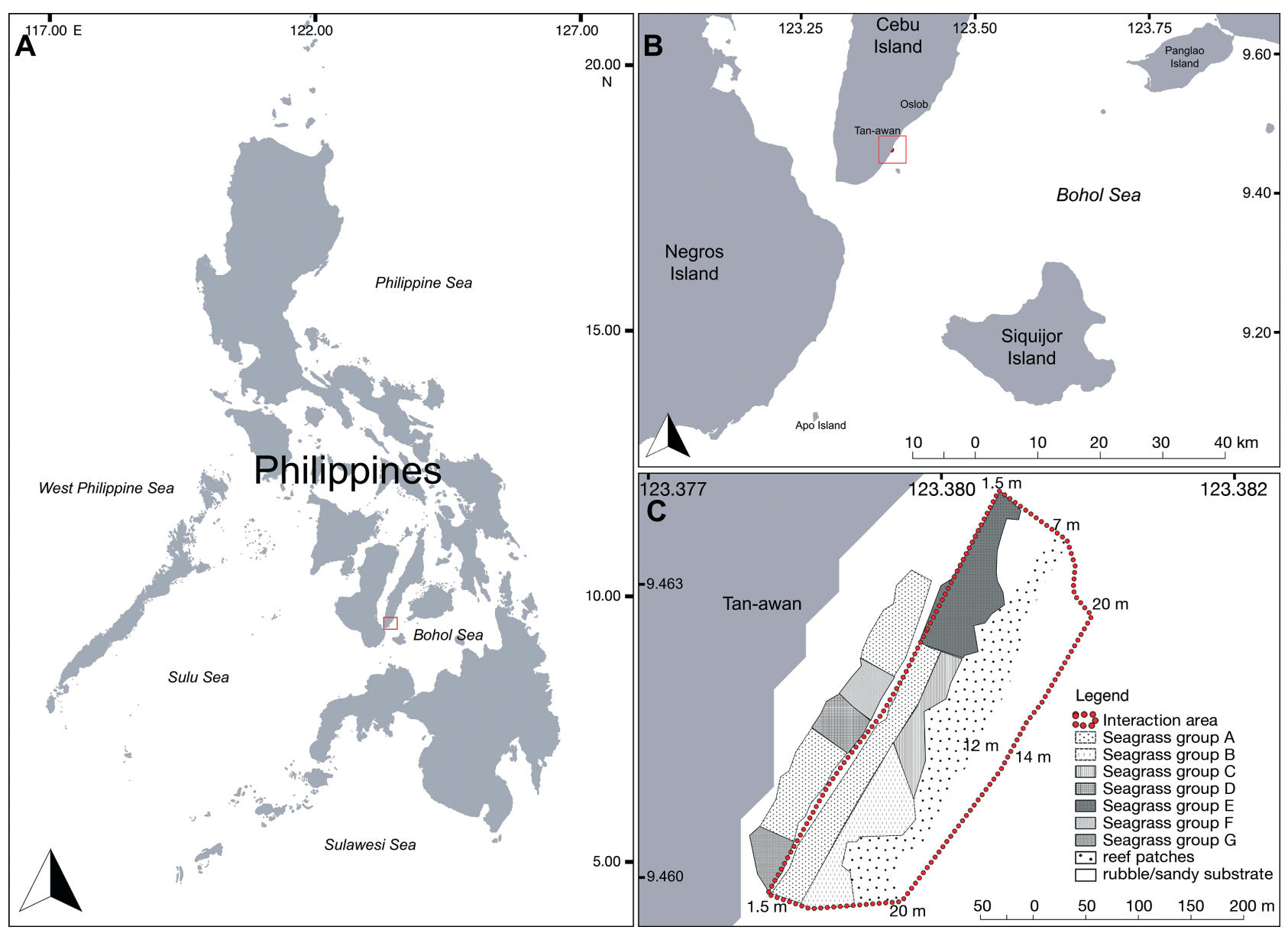

Fig. 1. (A) The Philippines, (B) western Bohol Sea and (C) the green turtle study site. Seagrass group A: Cymodocea serrulata, Halodule uninervis, H. ovalis, H. pinifolia, Syringodium isoetifolium; group B: C. serrulata, H. uninervis, H. ovalis, S. isoetifolium; group C: C. serrulata, H. uninervis, H. pinifolia, S. isoetifolium; group D: $H$. pinifolia, H. ovalis, C. serrulata; group E: $H$. uninervis, H. ovalis, S. isoetifolium, H. pinifolia; group F: H. pinifolia, H. ovalis, Thalassia hemprichii, S. isoetifolium, C. serrulata; group G: C. serrulata, H. ovalis, H. pinifolia, S. isoetifolium

ble. No strobes or flash were used during photo identification. A minimum distance of $2 \mathrm{~m}$ was kept between the researcher and the turtle for identification purposes. Following the collection of photo-ID data, the turtle's behaviour was noted again. The SCL was visually estimated at the end of each encounter in $5 \mathrm{~cm}$ increments. Although this method is prone to bias and error even with experienced researchers, it can help categorise the size class of individuals at the study site (Sequeira et al. 2016). Here, we defined an encounter as the successful identification of a turtle at a specific place and time.

\subsection{Photo-ID validation}

Photo-ID data was visually matched against a local database containing left and right identification images for each turtle. Once the turtles had been identified by a first researcher, these were then checked and validated by a second researcher. We then employed the pattern-recognition software ${ }^{3} \mathrm{~S}$ Pattern (www. reijns.com/i3s) to confirm researchers' visual identifications. Only images assessed to be $<30^{\circ}$ from a right angle to the right or left facial scutes of the turtle were used, as recommended in the software manual. All validated turtle encounters were subsequently input into a spreadsheet for further analyses.

\subsection{Biometric methodologies}

Following initial identification of individual turtles as described above, turtles were measured using paired-laser photogrammetry methods described by Araujo et al. (2016) in October-November 2017 and 
in September-October 2018. For consistency, we selected images for measurement that were taken from 2-3 $\mathrm{m}$ from the carapace. A paired-laser photogrammetry encounter yielded between 1 and $>50$ images if the turtle was undisturbed. All photographs that appeared to be $>10^{\circ}$ from the longitudinal midline of the carapace were discarded, yielding a total of 403 images for measurements (1-44 per turtle measured). Turtles measured by Araujo et al. (2016) in October and December 2015 were used to assess their growth rates. Growth rates $\left(\mathrm{cm} \mathrm{yr}^{-1}\right)$ were calculated as $\Delta$ SCL $/ t$ (Seminoff et al. 2002), where $\Delta$ SCL is the $\mathrm{SCL}_{\text {final }}-\mathrm{SCL}_{\text {initial, }}$ and $t$ is the time interval between measurements.

To validate the accuracy of the paired-laser photogrammetry setup, we used a stereo-photogrammetry system known to be consistently accurate to $<5 \%$ error across different taxa. Two GoPro Hero 4 Silver cameras were placed $70 \mathrm{~cm}$ apart inside SeaGIS underwater housings (www.seagis.com.au). These were fixed to a stainless steel frame, and angled $\sim 8^{\circ}$ towards the centre of the frame. A researcher snorkelled the study site looking for turtles and followed the same protocol described above for laser-photogrammetry. The system was calibrated by measuring a calibration cube with multiple points set at known distances from each other, and distance measurements were conducted using the software CAL ${ }^{\odot}$ (www.seagis.com.au). The software EventMeasure ${ }^{\circledR}$ (www.seagis.com.au) calculates the length of objects in the field of view through a photometric network programmed during calibration of the system (see Harvey et al. 2002). Measurements were taken from right and left camera pairs of images of a turtle, manually selecting the start and end of an individual's carapace in each pair of images. Measurements with $<20 \mathrm{~mm}$ root mean square error were deemed acceptable (SeaGIS 2019).

We used a Shapiro-Wilks test for normality of the visual estimates, paired-laser and stereo photogrammetry measurements. We tested the homogeneity of variance among the different methods using Bartlett's test (Montgomery \& Runger 2007). Given the normality of the measurement data, we ran $t$-tests to test for significance among measurement methods.

\subsection{Drivers of turtle encounters}

In order to understand variability in turtle sightings at the study site, we recorded in-water observations and environmental variables. We used horizontal vis- ibility (m), swell (m), Beaufort sea state $(1,2,3,4,5)$, sea surface temperature $\left(\mathrm{SST}^{\circ}{ }^{\circ} \mathrm{C}\right)$, current (none, mild, moderate, strong), tide (time to high tide) and moon irradiance (\%). To avoid bias in time of day, only surveys starting at 10:00 $\mathrm{h}$ were used as these represented the majority of surveys $(\mathrm{n}=511)$ between February 2015 and October 2018. SST was extracted from NOAA's Optimum Interpolation SST v2 (NOAA/OAR/ESRL PSD; https://www.esrl.noaa. $\mathrm{gov} / \mathrm{psd} /$ ) using weekly averages with a $0.5 \times 0.5^{\circ} \mathrm{re-}$ solution. Daily averages were incomplete so weekly averages were used. We fit a generalised linear model using a binomial distribution (using package 'mass' in R) to test whether these variables affected turtle encounter rates (turtles identified per hour of survey). We used the 'drop1' function in $\mathrm{R}$, where each variable selection is tested independently with a chi-squared test, and used Akaike's information criterion (AIC) for model selection (Burnham \& Anderson 2002).

\subsection{Population modelling}

Modified maximum likelihood methods were used to model residency and LIR (the probability that a photo-identified individual will be resighted at the site after a certain time lag) for turtles at the study site (Whitehead 2001). In total, 8 models were tested against the empirical photo-ID data spanning $>6 \mathrm{yr}$, with varying parameters of population size, residency in and out of the study site, emigration, reimmigration, mortality or permanent emigration and population closure (see Table 1). Models were evaluated for goodness-of-fit using the quasi-AIC (QAIC) to account for data over-dispersion (Whitehead 2007). The best-fit model was then bootstrapped for 100 repetitions to provide $95 \%$ CI and SE. We used the 'Movement' module in the program SOCPROG 2.7 for these analyses (Whitehead 2009).

In order to estimate the population size, $N$ (as estimates of $N$ are not produced through the LIR methods described above), we normalised the data to account for effort using only captures and recaptures from 10:00 h surveys between October 2014 and October 2018, and applied an open population JollySeber model (adapted from Schwarz \& Arnason 1996) using the POPAN option in program MARK (White \& Burnham 1999). The model applied $x$ capture occasions to calculate capture probability $(p), x-$ 1 to determine apparent survival $(\varphi)$, probability of entry into the population occasion ${ }^{-1}(\beta)$, and super population size $(N)$. A logit-link function was fitted to 
constrain $\beta$ parameters to $<1$ to avoid convergence problems (White \& Burnham 1999).

All statistical analyses were conducted using program R v.3.4.4 (R Core Team 2018; www.R-project. org).

\section{RESULTS}

\subsection{Green turtle population}

At the study site in Tan-awan, we recorded a total of 6626 encounters with green turtles over a period of 1442 survey days between 12 May 2012 and 15 October 2018. The encounters were with 82 individual green turtles, based on their unique facial scute patterns. The longest period between first and last encounter occurred for individual COST7, over a period of $2343 \mathrm{~d}$ ( $6.4 \mathrm{yr})$. A further 9 individuals were identified with at least 5 yr between first and last encounters (Table $\mathrm{S} 1$ in the Supplement at www.intres.com/articles/suppl/n040p207_supp.pdf). Of the 82 individuals identified, $28 \%(\mathrm{n}=23)$ were only encountered once, contrasting with $22 \%(n=18)$ that were encountered on at least 100 survey days. We encountered $4.5 \pm 2.6$ (mean $\pm \mathrm{SD}$ ) individual turtles during the $1 \mathrm{~h}$ surveys (range: 0-13 ind.). Recruitment of newly identified individuals showed no sign of an asymptote for the duration of the study, indicating an open population at the site (Fig. 2).

\subsection{Drivers of turtle encounters}

A total of 511 sessions ( $1 \mathrm{~h}$ each) conducted between 6 February 2015 and 15 October 2018 were used to assess variables affecting turtle encounter rates at Tan-awan. Table S2 summarises the model outputs. Higher Beaufort sea state (Beaufort sea state of 3) negatively affected turtle encounter rates ( $p<$ 0.05 ). As expected, increasing visibility (in $\mathrm{m}$ ) was positively correlated with the number of turtles encountered $(p<0.01)$. Similarly, the higher the temperature, the more turtles were encountered on effort $(\mathrm{p}<0.01)$. A moderate current also increased the encounter rate $(p<0.05)$. No other variables were found to affect encounter rates (all $p>0.05$ ).

\subsection{Photogrammetry and growth rates}

We measured a total of 16 individual turtles using paired-laser photogrammetry between Octo-

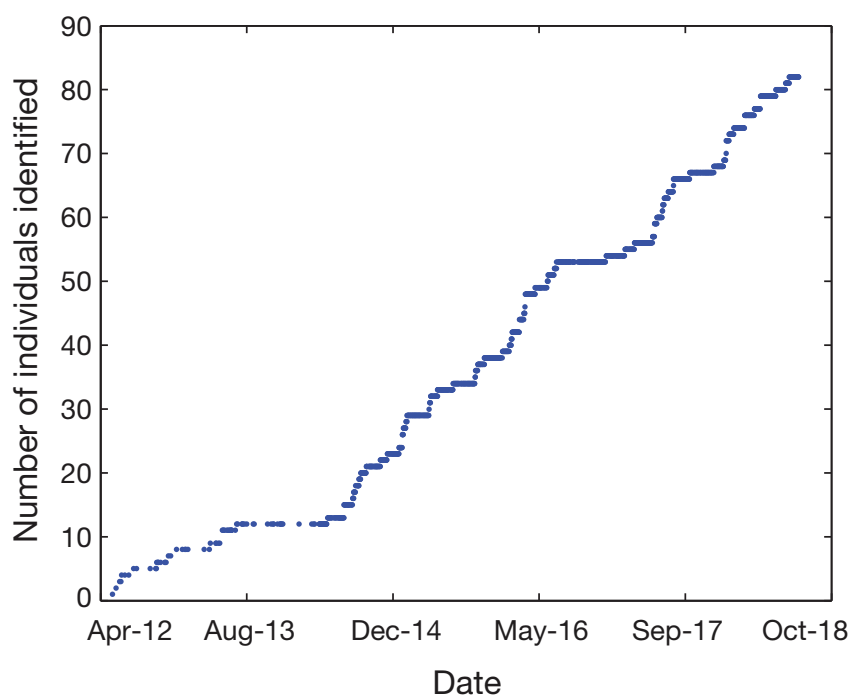

Fig. 2. Discovery curve of identified green turtles at Tanawan between April 2012 and October 2018

ber and December 2017, and 18 individuals between September and October 2018 (Table 1). The mean SCL for turtles in 2017 was $55.3 \pm 9.7 \mathrm{~cm}$ (range: $39.7-73.8 \mathrm{~cm}$ ), and $55.3 \pm 12.0 \mathrm{~cm}(38.6-$ $81.0 \mathrm{~cm}$ ) in 2018. The visually estimated mean SCL for those turtles measured in 2018 was $51.1 \pm$ $14.1 \mathrm{~cm}(28.6-80.3 \mathrm{~cm})$.

Twelve of the turtles had been previously measured in October-November 2015 by Araujo et al. (2016) using the same methods. These turtles were re-measured in 2017, and had a mean growth rate of $2.6 \mathrm{~cm} \mathrm{yr}^{-1}$. There were 12 turtles measured in 2018 that had also been measured in 2015 by Araujo et al. (2016), and these had a mean growth rate of $3.3 \mathrm{~cm}$ $\mathrm{yr}^{-1}$. Thirteen turtles measured in 2017 were re-measured in 2018, showing a mean growth rate of $4.4 \mathrm{~cm}$ $\mathrm{yr}^{-1}$, representing an overall growth rate for turtles at Tan-awan of $3.4 \mathrm{~cm} \mathrm{yr}^{-1}$.

We obtained stereo photogrammetry measurements for 22 turtles, with a mean SCL of $61.2 \pm$ $14.4 \mathrm{~cm}(43.3-94.4 \mathrm{~cm})$. Calibration measurements of the calibration cube following EventMeasure ${ }^{\circledR}$ protocol were consistently $<3 \%$ error $(n=52)$. Overall, visual and paired-laser photogrammetry tended to underestimate the size of the turtles. All size estimates are summarised in Table 1.

Visual estimates, paired-laser and stereo photogrammetry measurements were normally distributed (Shapiro-Wilks $\mathrm{p}=0.63,0.64$ and 0.19 respectively), with equal variance between them (Bartlett $p=0.72$ ). There was no significant difference between visual size estimates and paired-laser photogrammetry 
Table 1. Comparison of paired-laser photogrammetry measurements, visual estimates and stereo-photogrammetry measurements of SCL of green turtles. n/a: no measurements available

\begin{tabular}{|lccc|}
\hline Turtle ID & $\begin{array}{c}\text { Paired-laser photo- } \\
\text { grammetry }(\mathrm{cm})\end{array}$ & $\begin{array}{c}\text { Visual } \\
\text { estimates }(\mathrm{cm})\end{array}$ & $\begin{array}{c}\text { Stereo photo- } \\
\text { grammetry }(\mathrm{cm})\end{array}$ \\
\hline COST1 & 61.05 & 61.25 & 70.73 \\
COST3 & 80.95 & 80.25 & 94.35 \\
COST4 & 62.94 & 61.30 & 73.16 \\
COST5 & 65.52 & 63.16 & 78.23 \\
COST7 & 72.25 & 75.00 & 86.76 \\
COST8 & 61.65 & 55.33 & 73.69 \\
COST9 & 68.43 & 62.62 & $\mathrm{n} / \mathrm{a}$ \\
COST10 & 56.81 & 50.78 & 65.57 \\
COST11 & $\mathrm{n} / \mathrm{a}$ & $\mathrm{n} / \mathrm{a}$ & 68.81 \\
COST13 & 44.79 & 42.46 & 50.82 \\
COST14 & $\mathrm{n} / \mathrm{a}$ & $\mathrm{n} / \mathrm{a}$ & 64.47 \\
COST15 & 56.65 & 53.08 & 64.35 \\
COST29 & $\mathrm{n} / \mathrm{a}$ & $\mathrm{n} / \mathrm{a}$ & 62.51 \\
COST31 & 51.06 & 45.36 & 54.27 \\
COST32 & 51.97 & 45.74 & 57.32 \\
COST54 & $\mathrm{n} / \mathrm{a}$ & $\mathrm{n} / \mathrm{a}$ & 47.66 \\
COST67 & 46.41 & 42.62 & 50.41 \\
COST68 & 51.53 & 42.62 & 58.20 \\
COST69 & 42.74 & 39.00 & 48.49 \\
COST77 & $\mathrm{n} / \mathrm{a}$ & $\mathrm{n} / \mathrm{a}$ & 45.08 \\
COST85 & 42.01 & 39.00 & 44.50 \\
COST89 & 38.61 & 31.43 & $\mathrm{n} / \mathrm{a}$ \\
COST93 & 39.85 & 28.57 & 43.95 \\
COST94 & $\mathrm{n} / \mathrm{a} / \mathrm{a}$ & 63.33 \\
Mean & 55.29 & 51.09 & 14.36 \\
SD & 11.99 & 14.13 & 94.35 \\
Min. & 38.61 & 28.57 & \\
Max. & 80.95 & 80.25 & \\
\hline
\end{tabular}

\subsection{Residency and LIR}

With the entire data set, Model D (Table 2) was the best-fitting model with the lowest QAIC describing a closed population. However, the empirical data set clearly showed continued recruitment of individuals into the aggregation over time, indicating an open population (Fig. 2), and we therefore selected the next best-fitting model (Model $\mathrm{H}$ ) containing parameters for emigration, reimmigration, residency and mortality. The LIR decreased little, from 0.06-0.05 between 0 and $1000 \mathrm{~d}$, after which it steeply declined to 0.026 after $2100 \mathrm{~d}$ but never reached 0 (Fig. 3). The model estimated that a mean $( \pm \mathrm{SE})$ of $15.4 \pm 2.3$ (95\% CI: 12.0-20.3) turtles were present on any given day at the study site, and they remained for a mean of $56.4 \pm 5.5 \mathrm{~d}$ (46.5$65.4 \mathrm{~d})$, spending a mean of $4.5 \pm 2.9 \mathrm{~d}$ (0.1-10.7) outside the study site. Mortality or permanent emigration was estimated at $0.00022 \pm 0.00001$ (0.00005-0.00042) .

The POPAN extension open population model in program MARK (White \& Burnham 1999) for the period Octomeasurements $\left(T_{33}=-0.96, p=0.34\right)$, and no significant different between paired-laser and stereo photogrammetry measurements $\left(T_{38}=-1.42, \mathrm{p}=0.16\right)$. We found a significant difference in size estimates between visual and stereo measurements $\left(T_{37}=2.24\right.$, $\mathrm{p}=0.03)$. ber 2014 to October 2018 (79 unique IDs) converged to provide a population estimate for Tan-awan of 88.4 \pm 6.2 (81.9-109.5) individual turtles. This number does not represent the overall population of turtles at large, but rather the number of turtles utilising the site.

Table 2. Model results for modified maximum likelihood methods using parameters to test for green turtle population closure, mortality and permanent emigration, re-immigration and residency as preset in program SOCPROG 2.7 (Whitehead 2009).

N: population size; QAIC: quasi-Akaike information criterion. Bold text highlights the best-fit models

\begin{tabular}{|c|c|c|}
\hline Model & Parameters & $\triangle \mathrm{QAIC}$ \\
\hline A & Closed $(1 / \mathrm{a} 1=\mathrm{N})$ & 8116.9 \\
\hline B & Closed $(\mathrm{a} 1=\mathrm{N})$ & 8116.9 \\
\hline $\mathrm{C}$ & Emigration/mortality (a1 = emigration rate; 1 / a2 = N) & 278.6 \\
\hline D & $\begin{array}{l}\text { Closed: emigration }+ \text { reimmigration }(a 1=\text { emigration rate; } a 2 /(a 2+a 3)=\text { proportion of population } \\
\text { in study area at any time) }\end{array}$ & 0.0 \\
\hline E & Emigration/mortality ( $\mathrm{a} 1=\mathrm{N} ; \mathrm{a} 2=$ mean residence time) & 278.6 \\
\hline $\mathrm{F}$ & Emigration + reimmigration + mortality & 275.6 \\
\hline $\mathrm{G}$ & Emigration + reimmigration ( $\mathrm{a} 1=\mathrm{N} ; \mathrm{a} 2=$ mean time in study area; $\mathrm{a} 3=$ mean time out of study area) & 280.6 \\
\hline $\mathbf{H}$ & $\begin{array}{l}\text { Emigration }+ \text { reimmigration }+ \text { mortality }(\mathrm{a} 1=\mathrm{N} ; \mathrm{a} 2=\text { mean time in study area; } 3=\text { mean time out of } \\
\text { study area; } \mathrm{a} 4=\text { mortality rate })\end{array}$ & 264.1 \\
\hline
\end{tabular}






Fig. 3. Lagged identification rate (LIR) for green turtles at Tan-awan fitted through an emigration, reimmigration and mortality model (Model H, Table 1). Note the steady LIR to $1000 \mathrm{~d}$ before steeply declining. Error bars show SE

\subsection{Turtle behaviour}

We recorded a total of 4390 initial behaviours for 66 turtles between 14 July 2014 and 19 December 2017. Turtles were observed swimming $53 \%(n=2325)$ of the time, feeding $33 \%(\mathrm{n}=1461)$ and resting $14 \%$ ( $n=604$ ) of the time. We recorded changes in behaviour (i.e. feeding to swimming or resting to swimming) of individuals between the start and end of an encounter whilst collecting photo-ID on 1094 occasions, representing an overall change in behaviour in $25 \%$ of encounters. We used linear regression to determine whether the number of encounters influenced response for turtles with $\geq 5$ behavioural observations, and found no significance $\left(r^{2}=0.00503, p>\right.$ 0.05).

\section{DISCUSSION}

This study employed minimally invasive in-water techniques to understand the size, growth, behaviour, residency and abundance of green turtles at a juvenile aggregation in the Philippines. Some individuals displayed extended residency periods at Tan-awan, with recruitment to this coastal aggregation over time showing no signs of asymptote, indicating an open population. The in-water methods employed herein highlight improved accuracy and accessibility to turtles in order to assess populationlevel information (e.g. size class, residency, relative growth, behaviour). These methods are non-invasive in nature and although there are some inherent limitations, they present an alternative to conventional turtle studies that involve the live capture of animals.

Our results indicate, as expected, that visibility significantly affected encounter rate. Given that more than half of all encounters were recorded with freeswimming turtles, better visibility allowed for easier detection of the swimming individuals, and while it cannot be used as an indicator of turtle abundance, it can help design survey protocols. SST positively affected encounter rate. Green turtles are susceptible to changes in water temperature (e.g. Heath \& McGinnis 1980) and although the seasonal variance in the western Bohol Sea is ca. $3^{\circ} \mathrm{C}$ (Gordon et al. 2011), it is possible that turtles simply avoid or capitalise on foraging opportunities during specific hours of the day (Southwood et al. 2006). We used SST from remotely sensed data, with relatively low resolution that, in highly dynamic coastal ecosystems, is not sensitive enough to detect diurnal variations in turtle abundance, as perhaps in situ sampling or fitting temperature-depth recorder tags on the turtles would (e.g. Standora et al. 1984). Perception and availability bias may also affect detectability of turtles as highlighted by Williams et al. (2017). Future work should standardise data collection protocols, including visibility (to ensure unbiased detection of turtles in-water) and in situ temperature logging to fully elucidate the daily activity of turtles at the study site if accurate estimates of abundance are needed.

Paired-laser photogrammetry is a useful tool for determining the size and growth rates of Chelonia mydas in-water. Although our sample size was comparatively small, this aggregation displayed no apparent size-specific growth, which is similar to studies in Florida (Mendonça 1981) and, more locally, in Malaysia (Pilcher 2010a). Interestingly, the average growth rates reported here $\left(3.3 \mathrm{~cm} \mathrm{yr}^{-1}\right)$ are comparable to another juvenile aggregation in the region, at Mantanani in Sabah, Malaysia, where immature turtles grew on average $3.6 \mathrm{~cm} \mathrm{yr}^{-1}$ (Pilcher 2010a) and primarily feed on seagrasses (Halophila ovalis and Halodule uninervis). Similarly, at a remote atoll aggregation at TRNP in the Sulu Sea ca. $400 \mathrm{~km}$ southwest of Tan-awan, growth rates were $\sim 2.5 \mathrm{~cm}$ $\mathrm{yr}^{-1}$, also displaying monotonic rates (N. Pilcher pers. comm.). TRNP has been a well-managed MPA (Murray et al. 2018) for 3 decades, and thus this aggregation might have a higher density of turtles than Tanawan or Mantanani. Turtles at TRNP are known to feed on seagrasses, although some evidence of macroalgal ingestion exists (Pilcher 2010b). These 
results indicate that Southeast Asian tropical, juvenile-dominated aggregations feeding primarily on seagrasses have growth rates of $2.5-4 \mathrm{~cm} \mathrm{yr}^{-1}$, and reside for $6-15 \mathrm{yr}$ at these juvenile-dominated foraging grounds before moving on (Pilcher 2010a).

Although we found no significant difference in size estimates between paired-laser photogrammetry measurements and visual estimates, the consistency provided by the laser approach and the lack of subjectivity that visual estimates inherently have makes it a more appropriate tool for determining relative growth (Rohner et al. 2015). Researchers consistently underestimated the sizes of turtles through visual estimates, as did the paired-laser photogrammetry measurements as validated by the stereo-video camera system, similar to the findings of Sequeira et al. (2016) on whale sharks. Interestingly, at Apo Island (Fig. 1B) $\sim 44 \mathrm{~km}$ south of Tan-awan, stereo-measured green turtles had a mean SCL of $61.0 \mathrm{~cm}(\mathrm{n}=$ 39; authors' unpubl. data), similar to those reported here. Our stereo-photogrammetry approach on turtles, a first for this taxa, failed to show significant differences in size measurements compared to pairedlaser estimates - but it did when compared to visual estimates, highlighting the need for consistency in measurements. The system employed here did produce consistent measurements with $<3 \%$ error, ideal for obtaining accurate measurements of animals within a population (e.g. Sequeira et al. 2016), estimating biomass (e.g. Langlois et al. 2012) or estimating the growth rates of individuals over time. However, as of 2019 the stereo-camera system, calibration cube and EventMeasure ${ }^{\odot}$ program cost >AUD $\$ 10000$, which can be a major deterrent, particularly in developing or poorly funded regions. Given the $<$ AUD \$1000 cost (in 2019) of the paired-laser system, which can still produce relatively accurate growth and size estimates, this system may be more practical for research in regions with budgetary restrictions. Some systems (e.g. Letessier et al. 2015, Delacy et al. 2017) have been developed, however, that produce similar accuracies at a lower cost ( AUD \$1500). Although some of these systems need further testing in the field, opportunities exist for higher-accuracy measurement systems that do not require the live capture of the target species. Method selection will ultimately be restricted by budget, logistics, politics involving the live-capture of turtles and research questions, and a compromise of these factors might be necessary.

Green turtles inhabiting Tan-awan displayed consistent recruitment over time with no sign of an asymptote, indicating an open population. The ex- tended residency and strong site fidelity displayed by turtles at Tan-awan is considerable ( $>6 \mathrm{yr})$, highlighting its importance for the estimated $~ 100$ turtles utilising the site. The LIR used here estimated low mortality or permanent emigration rates, and residency within the site $>10$-fold over time spent outside. At any one capture opportunity, individual turtles spend a mean $\sim 56 \mathrm{~d}$ within the site with excursions outside of $<5 d$, suggesting the survey site does not fulfil $100 \%$ of the turtles' habitat needs (Whitehead 2001). The LIR showed that some turtles are indeed long-term residents (i.e. never reaching zero), yet some do leave the study site. The model cannot accurately estimate the LIR past the empirical data set ( 6.5 yr; Whitehead 2001). The risk of anthropogenic factors, including fishing pressure and pollution, to long-term resident animals is much greater, and management intervention is necessary (Stacey \& Taper 1992). Understanding these relationships in immature green turtles with foraging habitats during their developmental years (Meylan et al. 2011) has been highlighted as one of the priority areas of research for this Endangered species (Wildermann et al. 2018). Conservation objectives should focus on determining areas of importance for juveniles, as they comprise the major part of the population, and thus, its recovery potential (Heppel et al. 1996).

We recorded the behaviour of green turtles before and after collecting photo-ID data to understand changes to their behaviour, given the lack of in-water behavioural data on turtles. Overall, we found that turtles changed behaviour in $25 \%$ of encounters. Although we did not determine whether these changes were positive or negative, it is important baseline data to consider when designing guidelines for monitoring, including participatory science and in-water interactions with these animals. Hayes et al. (2017) found that recreational divers may negatively impact hawksbill turtles Eretmochelys imbricata, at least on a short-term scale, similar to that observed by Araujo et al. (2017) for whale sharks. It does, however, remain unclear whether these short-term impacts on wildlife might lead to long-term implications. Marine wildlife tourism has one of the highest growth rates in the tourism industry (Cater \& Cater 2007), presenting both opportunities (e.g. Huveneers et al. 2017) and threats to target species and their habitats (e.g. Orams 2000, Higham et al. 2016). Photo-ID has been successfully employed to engage the general public in monitoring of marine animal populations (e.g. whale sharks; Norman et al. 2017), although the implications of doing so are seldomly discussed. For 
turtles, in-water behavioural observations are limited and thus the design of accurate guidelines is not yet possible, although precautionary measures based on existing data are recommended (Griffin et al. 2017). We used a minimum distance of $2 \mathrm{~m}$ between researcher and turtle that yielded a $25 \%$ change in behaviour. Perhaps more studies on the minimum flight distance of green turtles to swimmers could help design guidelines, as could multi-sensory tags that record pitch and roll to estimate energetics of turtle responses to swimmers. These are important points to consider as 2 major turtle-based tourism sites have been recently developed in close proximity to Tan-awan, at Panglao and Apo Islands (see Fig. 1B).

\section{CONCLUSIONS}

Juvenile green turtles settle in neritic habitats where seagrass or algae appears to be the predominant food source. There is a need to further investigate immature turtles and their habitats, and this study has provided a variety of methodologies that can be employed to do so. Although stereo-photogrammetry produces accurate measurements, costrelated constraints are still considerable; however, development of open-access software and the lowercost camera systems will make this accurate technology more accessible. Photo-ID can be reliably used for green turtles for at least 11 yr (Carpentier et al. 2016, Ponzo et al. 2018), and as such it is a useful and accessible technique for monitoring immature aggregations. It is imperative that habitats where immature turtles are spending considerable amounts of time are identified and properly protected to safeguard the species' recovery, as this life stage makes up the major proportion of the population. Understanding where these immature turtles come from is also a key conservation question that can be elucidated by long-distance telemetry and genetic studies.

Our behavioural observations of green turtles' reactions to swimmers are only preliminary, and more research is needed as tourism with turtles develops locally and elsewhere. This, coupled with continued monitoring using photo-ID, can help manage turtles and their habitats on a localised level that can be used to inform management at other sites.

Acknowledgements. This study was done in collaboration with the Department of Environment and Natural Resources-Biodiversity Management Bureau (DENR-BMB), and DENR-Region 7. We thank the Local Government Unit of Oslob, mayor Jose Tumulak, TOSWFA association, and Elizabeth Benologa. This study was partly funded by NOAA Award NA17NMF4540115. Our work was made possible through the support and hard work of Large Marine Vertebrates Research Institute Philippines staff and volunteers. We acknowledge WWF-Philippines, particularly Marivel Dygico, for facilitating our stereo-photogrammetry work. We thank the 5 anonymous reviewers for their constructive comments that strengthened the manuscript.

\section{LITERATURE CITED}

Andrade MF, Domit C, Broadhurst MK, Tolhurst DJ, SilvaSouza ÂT (2016) Appropriate morphometrics for the first assessment of juvenile green turtle (Chelonia mydas) age and growth in the south-western Atlantic. Mar Biol 163:254

Araujo G, Montgomery J, Pahang K, Labaja J, Murray R, Ponzo A (2016) Using minimally invasive techniques to determine green sea turtle Chelonia mydas life-history parameters. J Exp Mar Biol Ecol 483:25-30

Araujo G, Snow S, So CL, Labaja J, Murray R, Colucci A, Ponzo A (2017) Population structure, residency patterns and movements of whale sharks in Southern Leyte, Philippines: results from dedicated photo ID and citizen science. Aquat Conserv 27:237-252

Baker JD, Littnan CL, Johnston DW (2006) Potential effects of sea level rise on the terrestrial habitats of endangered and endemic megafauna in the Northwestern Hawaiian Islands. Endang Species Res 2:21-30

Bjorndal KA, Bolten AB (1988) Growth rates of immature green turtles, Chelonia mydas, on feeding grounds in the southern Bahamas. Copeia 1988:555-564

Bjorndal KA, Bolten AB, Chaloupka MY (2000) Green turtle somatic growth model: evidence for density dependence. Ecol Appl 10:269-282

Bjorndal KA, Bolten AB, Chaloupka MY (2005) Evaluating trends in abundance of immature green turtles, Chelonia mydas, in the greater Caribbean. Ecol Appl 15:304-314

Bugoni L, Krause L, Petry MV (2001) Marine debris and human impacts on sea turtles in southern Brazil. Mar Pollut Bull 42:1330-1334

Burnham KP, Anderson DR (2002) Model selection and multimodel inference: a practical information-theoretic approach, $2^{\text {nd }}$ edn. Springer-Verlag, New York, NY

Carpentier AS, Jean C, Barret M, Chassagneux A, Ciccione S (2016) Stability of facial scale patterns on green sea turtles Chelonia mydas over time: a validation for the use of a photo-identification method. J Exp Mar Biol Ecol 476: $15-21$

Cater C, Cater E (2007) Marine ecotourism: between the devil and the deep blue sea. Ecotourism Series No. 6 . CAB International, Wallingford

Chaloupka M (2001) Historical trends, seasonality and spatial synchrony in green sea turtle egg production. Biol Conserv 101:263-279

Chassagneux A, Jean C, Bourjea J, Ciccione S (2013) Unravelling behavioral patterns of foraging hawksbill and green turtles using photo-identification. Mar Turtle Newsl 137:1-5

Cruz RD (2002) Marine turtle distribution in the Philippines. In: Kinan I (ed) Proc Western Pacific Sea Turtle Cooperative Research and Management Workshop, 5-8 Febru- 
ary 2002, Honolulu, HI. Western Pacific Regional Fishery Management Council, Honolulu, HI, p 57-66

*Delacy CR, Olsen A, Howey LA, Chapman DD, Brooks EJ, Bond ME (2017) Affordable and accurate stereo-video system for measuring dimensions underwater: a case study using oceanic whitetip sharks Carcharhinus longimanus. Mar Ecol Prog Ser 574:75-84

* Dunbar SG, Ito HE, Bahjri K, Dehom S, Salinas L (2014) Recognition of juvenile hawksbills Eretmochelys imbricata through face scale digitization and automated searching. Endang Species Res 26:137-146

Duran Najera JJ (1990) Nesting of three species of sea turtle in the northeast coast of the Yucatan Peninsula, Mexico. In: Richardson TH, Richardson JI, Donnelly M (eds) Proceedings of the $10^{\text {th }}$ Annual Workshop on Sea Turtle Biology and Conservation, 20-24 February 1990, Hilton Head, SC. NOAA Tech Memo NMFS-SEFC-278. Georgia Sea Turtle Cooperative, Athens, GA, p 29-33

Dutton PH, Jensen MP, Frutchey K, Frey A and others (2014) Genetic stock structure of green turtle (Chelonia mydas) nesting populations across the Pacific islands. Pac Sci 68: 451-464

Eckert K, Bjorndal K, Abreu-Grobois FA, Donnelly M (1999) Priorities for research in foraging habitats. In: Eckert KL, Bjorndal KA, Abreu-Grobois FA, Donnelly M (eds) Research and management techniques for the conservation of sea turtles. IUCN/SSC Marine Turtle Specialist Group Publication No. 4. IUCN, Gland, p 1-3

Gordon AL, Sprintall J, Ffield A (2011) Regional oceanography of the Philippine Archipelago. Oceanography 24: 14-27

KGriffin LP, Brownscombe JW, Gagné TO, Wilson AD, Cooke SJ, Danylchuk AJ (2017) Individual-level behavioral responses of immature green turtles to snorkeler disturbance. Oecologia 183:909-917

Groombridge B, Luxmoore R (1989) The green turtle and hawksbill (Reptilia: Cheloniidae): world status, exploitation and trade. Convention on International Trade in Endangered Species of Wild Fauna and Flora, Lausanne

Harvey E, Fletcher D, Shortis M (2002) Estimation of reef fish length by divers and by stereo-video: a first comparison of the accuracy and precision in the field on living fish under operational conditions. Fish Res 57:255-265

Harvey E, Fletcher D, Shortis MR, Kendrick GA (2004) A comparison of underwater visual distance estimates made by SCUBA divers and a stereo-video system: implications for underwater visual census of reef fish abundance. Mar Freshwat Res 55:573-580

Hayes CT, Baumbach DS, Juma D, Dunbar SG (2017) Impacts of recreational diving on hawksbill sea turtle (Eretmochelys imbricata) behaviour in a marine protected area. J Sustain Tour 25:79-95

Heath ME, McGinnis SM (1980) Body temperature and heat transfer in the green sea turtle, Chelonia mydas. Copeia 1980:767-773

Heppel SS, Limpus CJ, Crouse DT, Frazer NB, Crowder LB (1996) Population model analysis for the loggerhead sea turtle, Caretta caretta, in Queensland. Wildl Res 23: 143-161

Higham JE, Bejder L, Allen SJ, Corkeron PJ, Lusseau D (2016) Managing whale-watching as a non-lethal consumptive activity. J Sustain Tour 24:73-90

Huveneers C, Meekan MG, Apps K, Ferreira LC, Pannell D, Vianna GM (2017) The economic value of shark-diving tourism in Australia. Rev Fish Biol Fish 27:665-680
Jean C, Ciccione S, Talma E, Ballorain K, Bourjea J (2010) Photo-identification method for green and hawksbill turtles: first results from Reunion. Indian Ocean Turtle Newsl 11:8-13

Jennings S, Kaiser MJ (1998) The effects of fishing on marine ecosystems. Adv Mar Biol 34:201-352

Klimley AP, Brown ST (1983) Stereophotography for the field biologist: measurement of lengths and three-dimensional positions of free-swimming sharks. Mar Biol 74:175-185

Langlois TJ, Harvey ES, Meeuwig JJ (2012) Strong direct and inconsistent indirect effects of fishing found using stereo-video: testing indicators from fisheries closures. Ecol Indic 23:524-534

Lejano RP, Ingram H (2007) Place-based conservation: lessons from the Turtle Islands. Environ Sci Policy Sustain Dev 49:18-27

* Letessier TB, Juhel JB, Vigliola L, Meeuwig JJ (2015) Lowcost small action cameras in stereo generates accurate underwater measurements of fish. J Exp Mar Biol Ecol 446:120-126

Limpus CJ (1992) Estimation of tag loss in marine turtle research. Wildl Res 19:457-469

KLimpus C, Chaloupka M (1997) Nonparametric regression modelling of green sea turtle growth rates (southern Great Barrier Reef). Mar Ecol Prog Ser 149:23-34

Maison KA, Kelly IK, Frutchey KP (2010) Green turtle nesting sites and sea turtle legislation throughout Oceania. NOAA Tech Memo NMFS-F/SPO-110

* Mendonça MT (1981) Comparative growth rates of wild immature Chelonia mydas and Caretta caretta in Florida. J Herpetol 15:447-451

Meylan PA, Meylan AB, Gray JA (2011) The ecology and migrations of sea turtles 8 . Tests of the developmental habitat hypothesis. Bull Am Mus Nat Hist 357:1-70

Montgomery DC, Runger GC (2007) Applied statistics and probability for engineers, 4th edn. John Wiley \& Sons, Hoboken, NJ

Murray R, Conales S Jr, Araujo G, Labaja J and others (2018) Tubbataha Reefs Natural Park: first comprehensive elasmobranch assessment reveals global hotspot for reef sharks. J Asia-Pac Biodivers 12:49-56

* Norman BM, Holmberg JA, Arzoumanian Z, Reynolds SD and others (2017) Undersea constellations: the global biology of an endangered marine megavertebrate further informed through citizen science. Bioscience 67: 1029-1043

* Orams MB (2000) Tourists getting close to whales, Is it what whale-watching is all about? Tour Manage 21:561-569

Pilcher N (2007) Regional action plan for the conservation of marine turtles and their habitats in the Sulu-Sulawesi Seascape. Conservation International Philippines. Marine Research Foundation, Sabah

* Pilcher N (2010a) Population structure and growth of immature green turtles at Mantanani, Sabah, Malaysia. J Herpetol 44:168-171

Pilcher N (2010b) Population abundance, structure and dynamics of marine turtles in the Tubbataha Reefs, Cagayancillo, Palawan, Philippines. Field Report for the Tubbataha Reefs Natural Park. www.tubbatahareef.org/ download_research_reports/2010_sea_turtle_report.pdf

Pilcher NJ, Bali J, Buis J, Heng EC and others (2019) An overview of sea turtle satellite tracking in Malaysia. Indian Ocean Turtle Newsl 29:11-22

Ponzo A, Ong SA, Lamoste MJ, Micklem J and others (2018) Finding the balance: sea turtle tourism interaction in Apo 
Island, Philippines. In: 5th Int Mar Conserv Congr, 24-29 June 2018, Kuching. https://d2s6bxe5458gdv.cloudfront. net/imcc5-online-program.pdf

Poonian CN, Ramilo RV, Lopez DD (2016) Diversity, habitat distribution, and indigenous hunting of marine turtles in the Calamian Islands, Palawan, Republic of the Philippines. J Asia-Pacific Biodivers 9:69-73

R Core Team (2018) R: a language and environment for statistical computing. R Foundation for Statistical Computing, Vienna

Reisser J, Proietti M, Kinas P, Sazima I (2008) Photographic identification of sea turtles: method description and validation, with an estimation of tag loss. Endang Species Res 5:73-82

Rohner CA, Richardson AJ, Marshall AD, Weeks SJ, Pierce SJ (2011) How large is the world's largest fish? Measuring whale sharks Rhincodon typus with laser photogrammetry. J Fish Biol 78:378-385

Rohner CA, Richardson AJ, Prebble CE, Marshall AD and others (2015) Laser photogrammetry improves size and demographic estimates for whale sharks. PeerJ 3:e886

Sagun VG (2003) Marine turtles with foreign tags recaptured in the Philippines from 1993 to 2002. In: Arai N (ed) SEASTAR 2000: Proc 4th SEASTAR2000 Workshop, 1113 December 2003, Bangkok. Kyoto University, Kyoto, p 47-50

Sagun VG (2004) Postnesting movements of green turtles tagged in the Turtle Islands, Tawi-tawi, Philippines. Mar Turtle Newsl 104:5-7

Santana-Garcon J, Braccini M, Langlois TJ, Newman SJ, McAuley RB, Harvey ES (2014) Calibration of pelagic stereo BRUVs and scientific longline surveys for sampling sharks. Methods Ecol Evol 5:824-833

Schofield G, Katselidis KA, Dimopoulos P, Pantis JD (2008) Investigating the viability of photo-identification as an objective tool to study endangered sea turtle populations. J Exp Mar Biol Ecol 360:103-108

Schwarz CJ, Arnason AN (1996) A general methodology for the analysis of capture-recapture experiments in open populations. Biometrics 52:860-873

SeaGIS (2019) EventMeasure. https://www.seagis.com.au/ event.html (accessed 15 May 2018)

Seminoff JA (2004) Chelonia mydas. The IUCN Red List of Threatened Species 2004:e.T4615A11037468. doi:10. 2305/IUCN.UK.2004.RLTS.T4615A11037468.en

Seminoff JA, Resendiz A, Nichols WJ, Jones TT (2002) Growth rates of wild green turtles (Chelonia mydas) at a temperate foraging area in the Gulf of California, Mexico. Copeia 2002:610-617

Sequeira AM, Thums M, Brooks K, Meekan MG (2016) Error and bias in size estimates of whale sharks: implica-

Editorial responsibility: Mark Hamann,

Townsville, Queensland, Australia tions for understanding demography. R Soc Open Sci 3: 150668

Shortis M, Abdo EH (2016) A review of underwater stereoimage measurement for marine biology and ecology applications. Oceanogr Mar Biol 47:257-292

Solomon S, Qin D, Manning M, Chen Z and others (eds) (2007) Climate change 2007: the physical science basis. Contribution of Working Group I to the Fourth Assessment Report of the Intergovernmental Panel on Climate Change. Cambridge University Press, Cambridge

Southwood AL, Reina RD, Jones VS, Speakman JR, Jones DR (2006) Seasonal metabolism of juvenile green turtles (Chelonia mydas) at Heron Island, Australia. Can J Zool 84:125-135

Spitz SS, Herman LM, Pack AA (2000) Measuring sizes of humpback whales (Megaptera novaeangliae) by underwater videogrammetry. Mar Mamm Sci 16:664-676

Stacey PB, Taper M (1992) Environmental variation and the persistence of small populations. Ecol Appl 2: 18-29

Standora EA, Spotila JR, Keinath JA, Shoop CR (1984) Body temperatures, diving cycles, and movement of a subadult leatherback turtle, Dermochelys coriacea. Herpetologica 40:169-176

Trono RB (1991) Philippine marine turtle conservation program. Mar Turtle Newsl 53:5-7

*Van Tienhoven AM, Den Hartog JE, Reijns RA, Peddemors VM (2007) A computer aided program for pattern matching of natural marks on the spotted raggedtooth shark Carcharias taurus. J Appl Ecol 44:273-280

WWallace BP, Lewison RL, McDonald SL, McDonald RK and others (2010) Global patterns of marine turtle bycatch. Conserv Lett 3:131-142

White GC, Burnham KP (1999) Program MARK: survival estimation from populations of marked animals. Bird study 46(Supp1):S120-S139

Whitehead H (2001) Analysis of animal movement using opportunistic individual identifications: application to sperm whales. Ecology 82:1417-1432

Whitehead H (2007) Selection of models of lagged identification rates and lagged association rates using AIC and QAIC. Commun Stat Simul Comput 36:1233-1246

Whitehead H (2009) SOCPROG programs: analysing animal social structures. Behav Ecol Sociobiol 63:765-778

* Wildermann NE, Gredzens C, Avens L, Barrios-Garrido HA and others (2018) Informing research priorities for immature sea turtles through expert elicitation. Endang Spec Res 37:55-76

Williams JL, Pierce SJ, Rohner CA, Fuentes MM, Hamann $M$ (2017) Spatial distribution and residency of green and loggerhead sea turtles using coastal reef habitats in southern Mozambique. Front Mar Sci 3:288

Submitted: February 11, 2019; Accepted: September 10, 2019 Proofs received from author(s): November 15, 2019 